\title{
Dramaturgi Poligami
}

\author{
Rini Rinawati
}

\section{ABSTRACT}

Polygamy always creating conflicts, not only from non Islamic, but also inside Islamic people as well. Although polygamy is allowed by Islam, cultural barrier and negative perceptions spread among people made polygamy was practiced under hidden circumstance. This phenomenon created controversies, and an analysis based on dramaturgy theory of Goffmann would be best to examine the practice. The research found that management impression occurred both in back stage as well as in front stage. The actor is the husband who tried to improve his image by showing off his loyalty toward his first wife. Front stage and back stage are mixed, and in order to trace the genuine message, one must focus on nonverbal message implied in communication process among the pair(s).

Kata kunci: dramaturgi, poligami, pengelolaan kesan, front stage, back stage

\section{Pendahuluan}

\subsection{Latar Belakang Masalah}

"Dan jika kamu takut tidak akan dapat berlaku adil terhadap (hak-hak) perempuan yatim (bilamana kamu mengawininya), maka kawinilah wanita-wanita (lain) yang kamu senangi: dua, tiga, atau empat. Kemudian jika kamu takut tidak akan dapat berlaku adil, maka (kawinilah) seorang saja, atau budak-budak yang kamu miliki. Yang demikian itu adalah lebih dekat kepada tidak berbuat aniaya." (Surat AnNisa; ayat 3)

Ayat yang telah diwahyukan oleh Allah swt kepada Nabi Muhammad saw ini (Surat An-Nisa : 3) menjadi pijakan dari hukum dibolehkannya seorang laki-laki Muslim untuk mempunyai istri lebih dari 1 (satu) orang yang sering disebut dengan Poligami. Poligami menurut Mulia (2007:43), adalah ikatan perkawinan dalam hal mana suami mengawini lebih dari satu istri dalam waktu yang sama. Poligami merupakan syariat Islam yang akan berlaku sepanjang zaman hingga hari akhir.

Poligami diperbolehkan dengan syarat sang suami memiliki kemampuan untuk adil di antara para istri. Yang dimaksud dengan adil di sini adalah memberikan sesuatu kepada seseorang sesuai dengan haknya. Berlaku adil dalam ber-muamalah dengan istri-istrinya, yaitu dengan memberikan kepada masing-masing istri hak-haknya. Adil di sini lawan dari curang, yaitu memberikan kepada seseorang kekurangan hak yang dipunyainya dan mengambil dari yang lain kelebihan hak yang dimilikinya. Jadi, adil dapat diartikan persamaan. Berdasarkan hal ini maka adil antarpara istri adalah menyamakan hak yang ada pada para istri dalam perkara-perkara yang memungkinkan untuk disamakan di dalamnya.

Tidak bisa dipungkiri bahwa poligami terjadi 
di masyarakat kita, apa pun status sosial dan ekonominya, maupun dari berbagai latar belakang suku, agama, dan rasnya. Poligami tak hanya terjadi di kalangan pejabat, tetapi di semua lapisan masyarakat dalam segala macam strata sosial.

Memang Isu poligami tidak pernah ada habisnya. Selalu saja menarik untuk dibahas dan ditelaah. Ada yang pro dengan poligami berdasarkan rujukan ayat Al-Quran di atas yang manyatakan bahwa sebagai orang Islam kita wajib membenarkan adanya hukum yang membolehkan poligami. Sementara, yang kontra (anti poligami) menyatakan bahwa poligami merupakan bentuk kekerasan kepada istri, karena poligami merupakan keputusan sepihak dari suami ketika istri tidak mempunyai keberanian untuk menolak (dan tak punya kekuatan untuk melawan) disebabkan budaya patriarki, agama, dan ketergantungan ekonomi, maka kebanyakan poligami menyebabkan kekerasan pada perempuan dan anak, baik fisik maupun psikis.

Islam adalah agama rahmat untuk semua umat manusia di dunia ini. Tidak hanya umat Muslim sendiri, tapi juga umat yang beragama lain. Dengan demikian kita sangat percaya bahwa Islam memberikan "peluang" bagi seluruh umatnya untuk memiliki pandangan yang berbeda atau beropini dalam menanggapi isu-isu yang dialami manusia di dalam kehidupan, khususnya poligami.

Nah, sekarang isu poligami kembali merebak ke permukaan masyarakat Indonesia setelah Kiai kondang, Aa Gym, menikah lagi dan mempraktikkan poligami. Pada konferensi pers yang dilakukannya beberapa waktu lalu, ia dengan tegas mengakui bahwa dirinya mempraktikkan poligami yang di-iyakan oleh istri pertamanya, Teh Ninih. Banyak kalangan yang kecewa dan marah terhadap keputusan Aa Gym, terutama kalangan perempuan.

Sebagian besar dari mereka menyesalkan keputusan yang dilakukan Aa Gym karena menyakiti perasaan Teh Ninih dan jutaan perempuan di Indonesia . Tindakan yang dilakukan Aa Gym ini dikhawatirkan akan memberikan contoh buruk bagi generasi muda. Bagi sebagian kalangan, apa yang dilakukan Aa Gym tersebut akan "menodai" reputasi atau image-nya di depan publik. Dan itu memang mungkin saja terjadi. Karena pada kenyataanya, Aa Gym selama ini dikenal sebagai seorang Kiai yang mampu menarik hati berbagai kalangan, tidak saja kalangan menengah ke bawah, tapi juga kalangan atas (kalangan yang lebih sulit untuk didekati secara religius).

Komunikasi yang dilakukan para bapak yang melaksanakan praktik poligami, tentunya akan disesuaikan dengan istri-istrinya. Ketika manusia berinteraksi dengan sesamanya, ia ingin mengelola kesan yang ia harapkan tumbuh pada orang lain terhadapnya. Untuk itu, setiap orang melakukan pertunjukan bagi orang lain. Hal ini akan tercermin dari perilaku yang ditampilkannya, seperti pengakuan salah seorang bapak yang mempunyai istri 2 (dua) orang, sebut saja Bapak $\mathrm{U}$, yang menjelaskan bahwa:

Istri kedua saya memang dari sisi usia lebih muda 25 tahun dari saya, namun pemikiran dia lebih dewasa dari istri pertama saya, sehingga kami lebih sering nyambung ngobrolnya. Saya lebih enak kalo bersama istri kedua, dia tidak manja. Sementara, istri kesatu saya itu manja, segala maunya harus ditepati, saya harus banyak "ngalah", kalo tidak, dia akan cemberut. (wawancara dengan Bapak $U$ )

Dengan demikian, konteks komunikasi antara bapak yang berpoligami dengan para istrinya akan melibatkan aspek verbal dan nonverbal yang tidak jarang turut menentukan kelancaran bahkan keharmonisan hubungan dengan semua istriistrinya.

\subsection{Pertanyaan Penelitian}

Dari latar belakang yang telah diuraikan sebelumnya, maka yang mejadi fokus dari kajian ini adalah "bagaimana impression management (pengelolaan kesan) yang dilakukan para suami yang melakukan poligami di hadapan para istrinya?"

\subsection{Tujuan}

Penelitian dilakukan dengan tujuan untuk memperoleh gambaran mengenai perilaku yang ditampilkan. Atau dengan kata lain, pengelolaan kesan pada front stage dan back stage oleh para 
suami yang berpoligami dalam melakukan komunikasi dengan istri-istrinya melalui perilaku verbal dan nonverbal yang dilakukan.

\section{Kajian Pustaka}

\subsection{Dramaturgi}

Dramaturgis dikembangkan oleh Goffman, yang menganggap bahwa kehidupan manusia ibarat teater atau panggung sandiwara. Dalam perspektif ini, kehidupan manusia diibaratkan dengan panggung teater. Interaksi sosial mirip dengan pertunjukan di atas panggung, yang menampilkan peran yang dipertunjukkan oleh para aktor.

Selanjutnya, Goffman dalam Mulyana (2001: 107-114) mengatakan bahwa pendekatan dramaturgis merupakan pandangan bahwa ketika manusia berinteraksi dengan sesamanya, ia ingin mengelola kesan yang ia harapkan tumbuh pada orang lain terhadapnya. Untuk itu, setiap orang melakukan pertunjukan bagi orang lain.

Pada gilirannya, Goffmann mengasumsikan bahwa ketika orang-orang berinteraksi, mereka ingin menyajikan suatu gambaran diri yang akan diterima orang lain. Inilah yang disebut dengan "pengelolaan kesan " atau impression management, yaitu teknik-teknik yang digunakan aktor untuk memupuk kesan-kesan tertentu dalam situasi tertentu untuk mencapai tujuan tertentu.

Menurutnya Goffman, kehidupan sosial itu dapat dibagi menjadi wilayah depan dan wilayah belakang. Untuk memainkan peran sosial tersebut, biasanya sang aktor menggunakan bahasa verbal dan nonverbal serta mengenakan atribut-atribut tertentu yang sesuai dengan perannya dalam situasi tertentu. Aktor harus memusatkan pikiran agar ia tidak salah, sehingga harus menjaga diri, melakukan gerak-gerik, menjaga nada suaru, dan mengekspresikan wajah yang sesuai dengan situasi yang ada dalam tuntutan cerita. Wilayah depan disebut juga front region atau front stage, merujuk pada peristiwa sosial yang memungkinkan individu bergaya atau menampilkan peran formalnya yang ditonton khalayak penonton. Panggung atau wilayah depan (front region), terdiri dari:

(1) Front Pribadi (personal front), yang terdiri dari alat-alat yang dapat dianggap sebagai perlengkapan yang dibawa sang aktor, dan juga bahasa (verbal dan nonverbal).

(2) Setting, yaitu situasi fisik yang harus ada ketika sang aktor melakukan pertunjukan seperti: ruang periksa untuk dokter, ruang kuliah untuk guru, dsb.

Wilayah belakang disebut juga back region atau back stage, yaitu bagian belakang panggung tempat di mana para aktor mempersiapkan diri, bersantai atau berlatih. Panggung belakang biasanya berbatasan dengan panggung depan, namun tersembunyi dari pandangan khalayak untuk melindungi rahasia pertunjukan.

Berkenaan dengan dramaturgis ini Mulyana (2001:106) mengatakan bahwa inti dari dramaturgi adalah menghubungkan tindakan dengan makna, alih-alih perilaku dengan determinannya. Dalam pandangan dramaturgis tentang kehidupan sosial, maka makna bukanlah warisan budaya, sosialisasi, atau tatanan kelembagaan, atau perwujudan dari potensi psikologis dan biologis, melainkan pencapaian problematik interaksi manusia dan penuh dengan perubahan, kebaruan, dan kebingungan. Namun lebih penting lagi, makna bersifat behavioral, secara sosial tetap berubah, arbiter, dan merupakan ramuan interaksi manusia.

Dengan demikian, fokus dari pendekatan dramaturgis bukan pada "apa yang orang lakukan", atau "apa yang ingin mereka lakukan", atau "mengapa mereka melakukan", melainkan pada "bagaimana mereka melakukan". Sehubungan dengan hal itu, maka yang menjadi fokus dalam penelitian poligami yang berhubungan dengan pengelolaan kesan ini adalah bagaimana para suami yang melakukan poligami mengelola kesan di wilayah depan istri yang satu maupun wilayah belakangnya, di mana hal itu dilihat dari bahasa verbal dan nonverbal yang ditampilkan dalam proses komunikasi bersama istri-istrinya

\subsection{Kajian Komunikasi Verbal dan Nonverbal}

Komunikasi merupakan hal yang sangat 
penting bagi individu dalam melakukan interaksi. Komunikasi adalah proses saling memahami yang dilakukan para peserta komunikasi melalui transaksi makna. Gorden (dalam Mulyana, 2007:76) menjelaskan bahwa komunikasi, secara ringkas dapat didefinisikan sebagai suatu transaksi dinamis yang melibatkan gagasan dan perasaan. Sementara itu, Rosengren (dalam Mulyana, 2007:76) berpendapat bahwa komunikasi merupakan interaksi subjektif purposif melalui bahasa manusia yang berartikulasi ganda berdasarkan simbol-simbol.

Komunikasi pada gilirannya akan melibatkan proses pemaknaan terhadap bahasa verbal dan bahasa nonverbal. Bahasa verbal adalah seperangkat simbol, dengan aturan untuk mengombinasikan simbol-simbol tersebut yang digunakan dan dipahami suatu komunitas. 'Pesanpesan verbal tidak hanya meliputi bagaimana kita berbicara dengan orang lain, namun juga kegiatan internal-internal berpikir dan pengembangan makna kata-kata yang digunakan. Proses-proses ini (bahasa-bahasa verbal dan pola berpikir) secara vital berhubungan dengan persepsi dan pemberian serta pernyataan makna" (Mulyana, 2005:30).

Dengan demikian, bahasa merupakan alat utama yang digunakan dalam sebuah proses komunikasi. Bahasa menjadi alat dalam menyampaikan pola pikir seseorang, pada gilirannya bahasa juga akan menjadi penanda dari pola pikir itu sendiri, karena sistem linguistik (tata bahasa) dari suatu bahasa bukan hanya sekadar alat penyampai gagasan, tetapi sebagai pembentuk gagasan dan pemandu aktivitas manusia.

Sebagai sebuah penanda realitas, bahasa mempunyai fungsi untuk penamaan (naming atau labeling), sebagai sarana untuk berhubungan dengan orang lain, dan memungkinkan kita saling memahami mengenai diri, kepercayaankepercayaan, dan tujuan-tujuan. Namun demikian, bahasa verbal memiliki berbagai keterbatasan (Mulyana,2007:269-279), yaitu:

(1) Keterbatasan jumlah kata yang tersedia untuk mewakili objek.

(2) Kata-kata bersifat ambigu dan kontektual.

(3) Kata-kata mengandung bias budaya.
(4) Pencampuradukan fakta, penafsiran, dan penilaian.

Dengan berbagai keterbatasan yang dipunyai bahasa verbal, maka komunikasi akan efektifbila melibatkan bahasa nonverbal. Kita memang mempersepsi manusia tidak hanya lewat pesan verbal, tetapi juga lewat bahasa nonverbalnya. Albert Mehrabian (dalam Mulyana,2007:351), menyatakan bahwa 93\% dari semua makna sosial dalam komunikasi tatap muka diperoleh dari isyaratisyarat nonverbal. Mulyana (2001:310), menjelaskan bahwa pesan nonverbal adalah semua isyarat yang bukan kata-kata. Sementara, Sapir (dalam Senjaya, 1994:229) mengatakan bahwa komunikasi nonverbal adalah lambang yang disepakati, yang tidak tertulis di manapun, tidak jelas sumbernya, dan dimengerti oleh semua.

Selain itu, ahli lain yang menjelaskan komunikasi nonverbal adalah Samovar dan Porter dalam Mulyana (2003:310) yang menyatakan bahwa komunikasi nonverbal mencakup semua rangsangan (kecuali rangsangan verbal) dalam suatu setting komunikasi, yang dihasilkan oleh individu dan penggunaan lingkungan oleh individu, yang mempunyai nilai pesan potensial bagi pengirim dan penerima. Jadi, definisi ini mencakup perilaku yang disengaja juga tidak disengaja sebagai bagian dari peristiwa komunikasi secara keseluruhan: kita banyak mengirim pesan nonverbal tanpa menyadari bahwa pesan-pesan tersebut bermakna bagi orang lain.

Banyak isyarat nonverbal yang tidak bersifat universal, melainkan terikat oleh budaya. Namun, komunikasi nonverbal dapat dipelajari, bukan bawaan, dan hanya sedikit saja isyarat nonverbal yang merupakan bawaan seperti dikemukakan Mulyana (2003:309).

Goffman mengatakan bahwa di dalam permainan peran sosial, biasanya para aktor menggunakan bahasa verbal dan menampilkan perilaku nonverbal tertentu.

Terdapat beberapa alasan yang menjadikan pesan nonverbal begitu penting untuk dilakukan dalam proses komunikasi, seperti dikatakan Leathers dalam Rakhmat (2002:287-289), yaitu:

(1) Faktor-faktor nonverbal sangat menentukan 
makna dalam komunikasi interpersonal.

(2) Perasaan dan emosi lebih cermat disampaikan lewat pesan nonverbal ketimbang pesan verbal.

(3) Pesan nonverbal menyampaikan makna dan maksud relatif bebas dari penipuan, distorsi, dan kerancuan.

(4) Pesan nonverbal merupakan cara berkomunikasi yang lebih efisien dibandingkan dengan pesan verbal. Pesan nonverbal tidak perlu penjelasan tambahan seperti halnya dalam menyampaikan pesan verbal.

(5) Pesan nonverbal merupakan sarana sugesti yang paling tepat. Sugesti di sini dimaksudkan menyarankan sesuatu kepada orang lain secara implisit.

Duncan (dalam Rakhmat 2002: 289) menyebutkan, ada 6(enam) jenis komunikasi nonverbal, yaitu: kinesik atau gerakan tubuh, paralinguistik atau kualitas suara, proksemik atau penggunaan ruangan personal dan sosial, olfaksi atau penciuman, sensitivitas kulit, faktor artifaktual seperti pakaian dan kosmetik. Sementara, Burgoon dalam Littlejohn (1996:78) membagi komunikasi nonverbal dalam 7 (tujuh) jenis, yaitu: kinesics yaitu gerakan tubuh, proxemics atau penggunaan jarak; physical appereance, yaitu penampilan phisik; haptics ,yaitu penggunaan sentuhan; vocalics yaitu penggunaan suara, chronemics, penggunaan waktu; artifacts penggunaan barang-barang dalam penampilan diri.

(1) Bahasa Tubuh

Sering pula disebut dengan kinesics, yaitu menggunakan gerakan tubuh yang terdiri dari tiga komponen utama: pesan fasial, pesan gestural, dan pesan postural.

(2) Sentuhan (haptics)

Sentuhan sesorang akan memberikan makna yang berbeda, tergantung pada konteks komunikasi yang dilakukan, juga tergantung budaya yang menjadi latar belakangnya. Nilai berkomunikasi melalui sentuhan dianggap sangat penting dalam komunikasi antar manusia, seperti halnya bagi para pasangan suami-istri, apalagi yang mempunyai istri lebih dari satu.

(3) Parabahasa

Parabahasa atau vokalic adalah aspek dari suara selain ucapan, yang meliputi kecepatan berbicara, nada suara (tinggi/rendah), intensitas (volume) suara, intonasi, kualitas vokal (kejelasan), warna suara, dsb. Parabahasa ini akan memberikan simbol tentang perasaan yang akan mempengaruhi efektivitas komunikasi di antara pasangan suami istri.

(4) Penampilan Fisik (Phisical Appreance) Penampilan fisik atau disebut dengan physical appereance seseorang akan mempengaruhi proses komunikasi. Setiap orang memang punya persepsi mengenai penampilan fisik, baik itu busananya dan juga ornamen lain yang dipakainya. Kita memang cenderung mempersepsi dan memperlakukan seseorang dengan cara berbeda bila ia mengenakan pakaian berbeda. Bahkan, sebagian orang berpandangan bahwa pilihan atas busana mencerminkan kepribadian, demikian pula penampilan suami di hadapan istri-istrinya yang berbeda.

(5) Proksemik (Proxemics)

Pesan Proxemics disampaikan dalam pengaturan jarak dan ruang, yaitu bahasa nonverbal yang menyangkut orientasi ruang dan jarak pribadi. Hall dalam Tubbs (2001: 119) menberi nama khusus untuk kajian ruang ini dengan nama proksemika (proxemics), jarak spasial yang digunakan manusia ketika berkomunikasi dengan orang lain tergantung pada transaksi, hubungan individu yang berinteraksi, bagaimana perasaan mereka dan apa yang akan mereka lakukan. Hall menggambarkan hubungan manusia berdasarkan empat jenis jarak, yaitu: jarak intim, jarak pribadi, jarak sosial, dan jarak publik. Masing-masing mempunyai spesifikasi yang berbeda. Setiap budaya punya cara khas dalam mengonseptualisasikan ruang dan jarak pribadi dalam komunikasi.

(6) Konsep waktu

Waktu menentukan hubungan antarmanusia. 
Pola hidup manusia dalam waktu dipengaruhi oleh budayanya. T.Hall dalam Mulyana (2001: 366 ) membedakan dua macam konsep waktu, yaitu monokronik ( M ) dan polikronik ( P). Penganut waktu $M$ cenderung lebih menghargai waktu, tepat waktu, dan membagibagi serta menepati jadwal waktu secara ketat. Mereka menekankan penjadwalan dan kesegeraan waktu. Penganut waktu P, cenderung lebih santai, berjalan lebih lambat, suka menunda-nunda pekerjaan. Waktu berhubungan erat dengan perasaan hati dan perasaan-perasaan manusia. Kronemika adalah studi dan interpretasi atas waktu sebagai pesan. Bagaimana orang mempersepsi waktu dan memperlakukan waktu secara simbolik menunjukkan jati diri seseorang.

(7) Pesan Artifaktual, pesan ini menggambarkan pemilihan dan penggunaan barang. Dalam hal ini berkaitan dengan jenis, kualitas, merek, seringkali hal ini berkaitan dengan gaya hidup. Barangbarang yang digunakan untuk memenuhi kebutuhan hidup manusia dalam interaksi manusia dianggap mengandung makna tertentu. Bahkan, adakalanya orang melakukan penipuan dengan menciptakan penampilan barang yang digunakan sedemikian rupa, sehingga tidak menyangka kalau orang tersebut ternyata penipu. Adakalanya kita terkecoh kepada penampilan seseorang yang demikian sederhana sehingga perlakuan terhadapnya terabaikan atau terlecehkan. Seringkali hal seperti ini terjadi karena pengaruh dari benda yang digunakannya.

\subsubsection{Teori Struktur Kumulatif}

Teori ini dikembangkan oleh Ekman dan Freisen. Teori struktur kumulatif membahas mengenai makna yang berkaitan dengan gerak tubuh dan ekspresi wajah (makna kinesik) dari seseorang pada pelaksanaan komunikasi. Menurut Ekman dan Freisen, komunikasi nonverbal akan merefleksikan dua hal, yaitu:

(1) Unsur kesengajaan atau ketidaksengajaan dari suatu tindakan
(2) Tindakan tersebut harus menyertai pesan verbal atau tidak.

Pada gilirannya, kedua tindakan tersebut menambah makna yang berkaitan dengan interaksi antara peserta komunikasi yang disebut sebagai "expresisive behavior".

Terdapat lima kategori dari "expresisive behavior", yaitu:

(1) Emblem; gerak tubuh atau ekpresi wajah yang memiliki nilai yang sama dengan bahasa verbal.

(2) Ilustrator; gerak tubuh atau ekpresi wajah yang mendukung atau melengkapi bahasa verbal.

(3) Regulator; tindakan yang disengaja, yang biasanya digunakan dalam percakapan.

(4) Adaptor; tindakan yang disengaja, yang digunakan untuk menyesuaikan tubuh dan menciptakan kenyaman bagi tubuh atau emosi.

(5) Affect display; penggambaran emosi yang disengaja atau tidak, dapat mnyertai bahasa verbal maupun berdiri sendiri.

\subsubsection{Teori Analogi Kultural}

Teori analogi kultural yang dikembangkan oleh Edward T. Hall, membahas komunikasi nonverbal dari aspek proksemik dan kromenik. Proksemik mengacu kepada penggunaan ruang yang disebutnya sebagai lingkungan, teritorial, dan personal. Smentara, kronemik mengacu pada penggunaan waktu dalam berkomunikasi.

Edward T. Hall membagi wilayah ruang dalam tiga jenis ruang, yaitu:

(1) Informal space; ruang terdekat yang mengitari kita (personal space). Preferensi ruang seseorang ditentukan oleh delapan faktor:

(a) Jenis kelamin

(b) Sudut pandang (angle) yang terbentuk oleh bahu dan dada/punggung dari orang yang berkomunikasi

(c) Posisi badan ketika berkomunikasi

(d) Sentuhan ketika berkomunikasi

(e) Persepsi tentang panas tubuh ketika berkomunikasi

(f) Bau yang tercium ketika berkomunikasi

(g) Volume suara 
(2) Fixed-feature space; benda dilingkungan kita yang relatif sulit bergerak atau dipindahkan.

(3) Semifixed-feature space; barang-barang yang dapat dipindahkan yang berada dalam fixedfeature space.

Pada wilayah kronemik yang mengacu kepada penggunaan waktu sebagai salah satu tanda nonverbal, Hall menjelaskan bahwa norma-norma waktu ditemukan dalam dalam berbagai kultur dalam bentuknya yang berbeda-beda. Waktu merupakan komponen penting dalam komunikasi. Dengan waktu (pagi, siang, sore, dan malam) akan memberikan makna yang berbeda terhadap suatu pesan, yang pada gilirannya tentu akan memberikan reaksi yang berbeda pula pada perilaku yang ditampilkan dalam proses komunikasi tersebut.

\subsection{Poligami dalam Islam}

Berdasarkan sejarah, sebelum Islam masuk, masyarakat Arab telah mengenal poligami dan perbuatan zina. Pada waktu itu orang arab beristri lebih dari satu, dan dengan berpoligami justru mendapat penghormatan masyarakat karena hal itu menandakan bahwa orang Arab tersebut mempunyai kemampuan dalam memberikan materi terhadap istri-istrinya. Sementara itu, dari kaum wanita yang suaminya beristri lebih dari satu juga merasa bangga dan terhormat karena terangkatnya kedudukan suami.

Dalam pelaksanaannya, poligami yang berlangsung saat itu tidak mengenal batas, baik dalam hal jumlah istri maupun syarat moralitas keadilan, sehingga yang sering terjadi adalah adanya kekerasan (alih-alih perbudakan) terhadap istri. Islam datang melakukan reformasi secara radikal terhadap perilaku poligami. Reformasi Islam menyangkut dua hal; pertama, membatasi jumlah istri hanya empat; dan kedua bahwa poligami hanya dibolehkan bagi suami yang menjamin keadilan untuk para istrinya. Islam juga berperan dalam pengangkatan derajat perempuan, hal tersebut dapat terlihat di mana perempuan yang tadinya hanya dianggap sebatas barang, bisa naik posisinya menjadi manusia dalam arti perempuan menjadi lebih dihargai. Dalam Al-Qur'an, perempuan ditempatkan paling tidak dalam tiga posisi, yaitu:

(1) Perempuan sebagai pendamping pria dalam mengarungi kehidupan rumah tangga, karena mereka adalah manusia yang satu.

Allah swt berfirman,: "Dan di antara tandatanda kekuasaan-Nya ialah Dia menciptakan untukmu istri-istri dari jenismu sendiri, supaya kamu cenderung dan merasa tenteram kepadanya, dan dijadikan-Nya di antaramu rasa kasih dan sayang. Sesungguhnya pada yang demikian itu benar-benar terdapat tanda-tanda bagi kaum yang berfikir"'(Q. S. Ar-Ruum: 21).

(2) Dalam membangun kehidupan masyarakat, satu sama lain menjadi mitra kerja bagi yang lainnya. "Orang-orang Mukmin laki-laki dan perempuan, sebagian mereka menjadi penolong bagi sebagian yang lain. Mereka memerintahkan kemakrufan dan mecegah kemungkaran" (QS at-Taubah [9]:71).

(3) Perempuan sebagai ibu pencetak generasi berkualitas. "Hai sekalian manusia, bertakwalah kepada Tuhanmu yang telah menciptakan kamu dari diri yang satu, dan dari padanya Allah menciptakan istrinya dan dari pada keduanya Allah mengembangbiakkan laki-laki dan perempuan yang banyak. Dan bertakwalah kepada Allah yang dengan nama-Nya kamu saling meminta satu sama lain...” (Q. S. AnNisaa' [4]:1).

Menurut Mubarak (2007:33), kita dapat melihat berbagai aspek poligami berdasarkan beberapa hal sebagai berikut:

(1) Hukum poligami

Para ulama fiqih telah memandang bahwa nikah menurut Islam dapat terjadi dalam hukum yang lima, yaitu: Jaiz (diperbolehkan), ini asal hukumnya; Sunat bagi orang yang berkehendak serta mampu memberi nafkah dan lain-lainnya; Wajib bagi orang yang mampu memberi nafkah dan dia takut akan tergoda pada kejahatan (zina); Makruh bagi orang yang tidak mampu memberi nafkah; Haram bagi orang yang berniat akan menyakiti perempuan 
yang dinikahinya.

(2) Jumlah istri

Tidak halal bagi seseorang untuk melakukan poligami lebih dari empat orang pada saat yang sama. Tinjauan historis empat orang istri bagi seorang suami bukanlah penambahan tapi pembatasan, karena ditemukan banyak orang yang memiliki istri lebih dari empat. Maka Rasulullah menegaskan kepada mereka agar dipilih dari jumlah tersebut empat orang dan yang lainnya agar dicerai dengan cara baik. Bila terjadi pandangan lain tentang jumlah istri maka hal tersebut muncul karena kekeliruan dalam memahami Al-Quran dan Sunnah Rasulullah saw.

(3) Syarat poligami

Tidak dibenarkan bagi seseorang untuk berpoligami tanpa memiliki persiapan dan kemampuan untuk berlaku adil. Barang siapa yang belum yakin bahwa dirinya akan mampu berlaku adil, maka dia tidak boleh menikah kecuali dengan seorang perempuan. Jika dia memaksakan menikahi lebih dari satu orang maka nikahnya sah tapi berdosa.

Dari Abu Hurairah r.a berkata, "Rasulullah saw bersabda, Barangsiapa menikah dengan dua istri, lalu dia cenderung kepada salah satu dari keduanya, maka nanti pada hari kiamat dia akan datang dalam keadaan lumpuh sebelah. " Dalam riwayat Affan (H.R. An Nasai).

(4) Tidak dalam satu keluarga

Poligami tidak dibenarkan dengan dua wanita yang bersaudara. Demikian pula dengan seorang wanita bersama bibinya, baik bibi dari pihak ayah ataupun dari pihak ibu.

Menurut Nashih 'Ulwan dalam Mubarak (2007:42-70), poligami yang berlangsung pada diri Rasulullah saw telah memainkan peran penting dalam penyebaran risalahnya, terutama dalam hal:

(1) Penyebaran ilmu Islam

Kaum wanita selalu memiliki populasi yang lebih besar dibanding pria. Mereka memerlukan bimbingan untuk menjadi orang yang berilmu dan berwawasan luas. Untuk memahami masalah-masalah tertentu, mereka sangat memerlukan pembimbing dari golongan wanita yang dapat menjelaskan dengan lebih rinci ketika seorang laki-laki merasa keberatan untuk menyampaikannya.

(2) Meraih dukungan dakwah

Tidak syak lagi bahwa tersebarnya dakwah Islamiyah ke seluruh masyarakat Arab disebabkan Rasulullah telah menikah dengan tokoh-tokoh wanita dari berbagai kabilah Quraisy. Quraisy adalah kabilah yang mempimpin Arab. Menurut sejarah, kabilahkabilah tersebut memberi respons positif kepada dakwah Rasulullah setelah beliau mengawini wanita dari kalangan mereka yang membuat mereka pun kemudian berduyunduyun masuk Islam dengan senang hati.

(3) Membuktikan kesempurnaan syariat Menurut tinjauan syariat, pernikahan Rasul dengan beberapa orang perempuan memiliki beberapa makna, antara lain:

(a) Menghapus Budaya Jahiliyah yang berhubungan dengan masalah adopsi;

(b) Bertugas menyebar hadis;

(c) Penerapan prinsip keadilan.

(4) Merealisasi prinsip bahu-membahu Sasaran poligami yang dilakukan oleh Rasulullah adalah memelihara anak yatim, menolong janda, dan menghibur wanita yang kena musibah.

(5) Memperkuat ikatan persahabatan

Sejak di Makkah, Abu Bakar dan Umar adalah dua sahabat yang sangat dekat dengan Rasulullah saw. Mereka berdua adalah sahabat awal yang mencurahkan segala upaya demi tegaknya kalimat tauhid. Kuatnya persahabatan mereka telah mengalahkan hubungan darah.

(6) Memberi teladan dalam perbaikan umat Rasulullah adalah suri teladan yang sempurna dalam segala aspek kehidupan, termasuk dalam bergaul dengan semua anggota keluarga. Beliau membawa semua anggota keluarganya menuju kebaikan. Beliau membagi waktu, kenikmatan, perjalanan, dan lainnya, dengan adil. Lebih jelas lagi di antaranya:

(a) Pembagian dengan adil; 
(b) Menghormati pendapat mereka;

(c) Membantu pekerjaan rumah tangga;

(d) Tidak pernah memukul;

(e) Selalu setia kepada istri kendati sudah wafat;

(f) Bergurau dan murah senyum.

\section{Subjek, Objek, dan Metodologi Penelitian}

\subsection{Subjek dan Objek Penelitian}

\subsubsection{Subjek Penelitian}

Subjek penelitian atau informan dalam penelitian ini adalah bapak-bapak yang melakukan poligami. Informan lain dalam penelitian ini adalah perempuan yang dipoligami (istri kesatu atau istri kedua) sebagai tambahan informasi dan juga sebagai "triangulasi" data yang diperolah dari subjek penelitian. Informan atau subjek penelitian diambil secara purposif, yaitu berdasarkan alasanalasan tertentu seperti suami yang melakukan poligami mewakili profesi tertentu dan juga mewakili peran tertentu dalam masyarakat. Cara pencarían informan dilakukan dengan bertanya kepada beberapa orang yang dikenal untuk memberikan rekomendasi yang melakukan poligami. Setelah itu, peneliti melakukan pendekatan personal dengan jalan menghubungi yang bersangkutan untuk meminta kesediaannya untuk diwawancara dalam penelitian ini.

\subsubsection{Objek Penelitian}

Objek yang dikaji dalam penelitian ini adalah perilaku komunikasi verbal dan nonverbal, yang dilakukan oleh para suami yang melakukan poligami, meliputi:

(1) Verbal, adalah bahasa yang digunakan seharihari dengan istri-istrinya

(2) Nonverbal, meliputi: proksemik, penampilan fisik, paralinguistik, sentuhan, kronemik, dan artifaktual.

Pesan verbal dan nonverbal selanjutnya akan dikaji dalam kaitan dengan pengelolaan kesan (dramaturgi), yang dilakukan oleh para suami yang berpoligami tersebut.

\subsection{Metodologi Penelitian}

\subsubsection{Metode Penelitian}

Penelitian ini dilakukan melalui pendekatan kualitatif, yang menurut Moleong (2004:6) adalah penelitian yang bermaksud memahami fenomena tentang apa yang dialami subjek penelitian, misalnya perilaku, persepsi, motivasi, tindakan, dan lain-lain, secara holistik yang dideskripsikan pada konteks khusus yang alamiah dan memanfaatkan berbagai metode alamiah. Penelitian dramaturgi poligami ini akan mengamati perilaku komunikasi verbal dan nonverbal dari para suami yang melakukan poligami.

\subsubsection{Desain Penelitian}

Sesuai dengan permasalahan dalam penelitian ini tentang bagaimana komunikasi verbal dan nonverbal dari para suami yang berpoligami dalam kehidupan sehari-hari mereka, maka pendekatan yang tepat digunakan dalam penelitian adalah pendekatan dramaturgis dari Erving Goffman, sebagaimana dikemukakan Mulyana (2001:107), "bahwa ketika manusia berinteraksi dengan sesamanya, ia ingin mengelola kesan yang ia harapkan tumbuh pada orang lain terhadapnya. Untuk itu setiap orang melakukan pertunjukan bagi orang lain".

\subsubsection{Teknik Penggalian Data}

Dalam penelitian kualitatif, teknik yang biasanya digunakan adalah : metode pengamatan, wawancara, dan pemanfaatan dokumen. Penelitian ini menggunakan teknik penggalian data melalui wawancara dan studi dokumentasi. Sementara, teknik observasi tidak peneliti lakukan, dikarenakan para informan tidak mengizinkan peneliti untuk melihat kehidupannya secara langsung bersama istri-istrinya. Hal ini dapat dipahami karena masalah poligami menjadi masalah yang kontroversi pada masyarakat kita.

Wawancara yang peneliti lakukan adalah dengan pertanyaan yang tidak terstruktur, terbuka, dan bersifat menggali informasi sebanyakbanyaknya. Untuk itulah wawancara mendalam dilakukan, sehingga hal-hal yang mendorong 
informan untuk melakukan dramaturgi melalui komunikasi verbal dan nonverbal mereka dalam berdramaturgi dapat digali sebanyak-banyaknya.

\section{Pembahasan}

\subsection{Pesan Verbal dalam Praktik Poligami}

Bahasa merupakan alat utama yang digunakan dalam sebuah proses komunikasi. Bahasa menjadi alat dalam menyampaikan pola pikir seseorang. Pada giliannya, bahasa juga akan menjadi penanda dari pola pikir itu sendiri, karena sistem linguistik (tata bahasa) dari suatu bahasa bukan hanya sekadar alat penyampai gagasan, tetapi sebagai pembentuk gagasan dan pemandu aktivitas manusia. Bahasa akan berkaitan langsung dengan bagaimana cara-cara kita berpikir dalam sesuatu. Karena kultur yang berbeda, maka mereka memiliki bahasa yang berbeda dan pandangan hidup yang berbeda, sehingga mereka memiliki keyakinan dan nilai-nilai yang berbeda pula.

Bahasa verbal yang digunakan oleh suami yang berpoligami akan sangat tergantung dari latarbelakang budaya (suku), baik dari suami itu sendiri maupun dari istrinya. Namun demikian, bahasa Indonesia sebagai bahasa nasional tetap mendominasi penggunaan bahasa yang dipergunakan.

Sebagai sebuah penanda realitas, bahasa mempunyai fungsi untuk penamaan (naming atau labeling), sebagai sarana untuk berhubungan dengan orang lain, dan memungkinkan kita saling memahami mengenai diri, kepercayaankepercayaan, dan tujuan-tujuan. Penamaan atau labeling berfungsi sebagai pembeda suatu objek dengan objek yang lain. Demikian juga sebutan terhadap seseorang. Pesan verbal dalam penelitian ini menyangkut kepada panggilan yang dilakukan para suami terhadap istri-istrinya. Hasil penelitian menunjukkan bahwa panggilan terhadap para istrinya dilakukan dengan nama yang sama. Hal ini dimaksudkan untuk memudahkan, di samping alasan kebiasaan. Alasan lain yang menarik adalah agar tidak terjadi kesalahan dalam memanggilan ketika sang suami ada di rumah istri kesatu maupun istri kedua.
Konsep dramaturgi menjelaskan bahwa seseorang cenderung untuk menampilkan sosok diri yang ideal sesuai dengan peran dia dalam panggung kehidupan itu sendiri. Goffmann mengasumsikan bahwa ketika orang-orang berinteraksi, mereka ingin menyajikan suatu gambaran diri yang akan diterima orang lain. Inilah yang disebut dengan "pengelolaan kesan " atau impression management, yaitu teknik-teknik yang digunakan aktor untuk memupuk kesan-kesan tertentu dalam situasi tertentu untuk mencapai tujuan tertentu.

Demikian pula dengan para suami yang melakukan poligami. Mereka berusaha menampilkan sosok ideal dengan mengelola kesan yang khusus melalui panggilan, namun menyembunyikan motif dari tindakan yang mereka tampilkan, sehingga mereka memperoleh kesan yang tetap, baik di mata istri pertama. Hal ini dikarenakan sejarah poligami pada awalnya tidak diketahui oleh istri pertama.

Impression management yang dilakukan oleh para pelaku poligami, khususnya yang tidak diketahui oleh istri pertama dalam hal bahasa verbal, akan sangat kentara. Hasil penelitian menunjukkan bahwa mereka yang poligaminya tidak diketahui oleh istri pertama, maka penggunaan bahasa verbal akan sangat ditentukan dengan berbagai faktor seperti: media komunikasi (telepon atau SMS); kehadiran orang lain atau lingkunagn tempat komunikasi tersebut terjadi.

\subsection{Pesan Nonverbal dalam Praktik Poligami}

Proses komunikasi yang dilakukan manusia tidak hanya melibatkan bahasa verbal saja, akan tetapi juga melibatkan bahasa nonverbal seperti gerakan tubuh, sentuhan, pakaian, jarak komunikasi, konsep waktu, dan lain sebagainya. Dalam rangka proses komunikasi para suami yang berpoligami, khususnya melalui kajian dramaturgi, bahasa nonverbal yang turut mempengaruhinya adalah: bahasa tubuh (kinesic), sentuhan (haptic), parabahasa (vokalic), penampilan fisik (termasuk didalamnya artefak), dan konsep waktu. 


\section{(1) Bahasa Tubuh}

Panggung depan, atau sering disebut sebagai front stage menjadi bagian penting dari para suami yang melakukan poligami. Pengelolaan di panggung depan ini dalam konsep dramaturgi pada gilirannya dilakukan dalam rangka mengelola kesan tentang citra dirinya sebagai seseorang yang sayang pada istri dan keluarganya. Bagi para suami yang poligaminya sudah diketahui istri pertama, mereka tetap menampilkan rasa sayang mereka seperti semula melalui sentuhan, belaian, dan sebagainya.

Demikian pula bagi suami yang poligaminya tidak diketahui oleh istri pertama, pengungkapan rasa sayang melalui pesan kinesik, tetap dapat dilakukan, sekalipun tentunya dengan sembunyisembunyi. Bahkan, dalam beberapa pertemuan yang tidak mengetahui bahwa suami tersebut berpoligami, sementara itu juga hadir istri kedua, maka hubungan yang terjadi menjadi hubungan yang formal seperti yang lainnya. Ini juga terjadi dalam pertemuan keluarga di mana istri kedua hadir. Ketika hubungan terjadi begitu formal maka bahasa tubuh akan menyesuaikan.

\section{(2) Sentuhan (haptics)}

Dramatugi sebagai sebuah konsep komunikasi dengan menggunakan setting panggung pesan nonverbal menjadi bagian penting yang perlu dilakukan dalam memupuk citra tertentu. Demikian pula dalam poligami yang dilakukan oleh para suami mereka perlu untuk memupuk kesan-kesan tertentu di hadapan para istrinya maupun yang lainnya.

Sentuhan sesorang akan memberikan makna yang berbeda, tergantung pada konteks komunikasi yang dilakukan, juga tergantung budaya yang menjadi latar belakangnya. Nilai berkomunikasi melalui sentuhan dianggap sangat penting dalam komunikasi antarmanusia, seperti halnya bagi para pasangan suami-istri.

Hal yang menarik dari hasil penelitian terhadap sentuhan yang dilakukan oleh para suami yang melakukan poligami adalah adanya perbedaan pemaknaan terhadap sentuhan yang ditampilkan oleh para suami yang berpoligami. Bagi suami yang berpoligami dengan istri kedua yang jauh usianya lebih muda, maka sentuhan yang dilakukan terhadap istri muda jauh lebih sering, sekalipun terhadap istri pertama juga dari sisi frekuensi tidak berkurang.

Demikian pula sentuhan, (belaian, misalnya) yang dilakukan menjadi lebih sering ditunjukkan terhadap istri pertama. Hal ini dilakukan untuk menunjukkan rasa sayang dia tidak menjadi berkurang sekalipun berpoligami. Atau mungkin sebagai bentuk excuse (maaf) dari perilaku poligami yang menjadi pembenaran (justification) sebagaimana dikembangkan dalam Accounts theory.

\section{(3) Parabahasa}

Parabahasa, atau vokalic, adalah aspek dari suara selain ucapan yang meliputi kecepatan berbicara, nada suara (tinggi/rendah), intensitas (volume) suara, intonasi, kualitas vokal (kejelasan), warna suara, dsb. Dalam sebuah proses komunikasi dalam kacamata dramaturgi, tentunya parabahasa memegang peranan penting untuk penampilan para aktor di panggung depan bagi pencapaian kesan tertentu di depan khalayak penonton. Perbedaan budaya yang dipunyai para peserta komunikasi (suami-istri) akan turut menentukan tampilan para bahasa dalam praktek poligami yang dilakukan oleh para suami.

\section{(4) Penampilan Fisik}

Penampilan fisik atau disebut dengan physical appereance seseorang akan mempengaruhi proses komunikasi. Setiap orang memang punya persepsi mengenai penampilan fisik, baik itu busananya dan juga ornamen lain yang dipakainya. Kita memang cenderung mempersepsi dan memperlakukan seseorang dengan cara berbeda bila ia mengenakan pakaian berbeda. Bahkan, sebagian orang berpandangan bahwa pilihan atas busana mencerminkan kepribadian, demikian pula penampilan suami dihadapan istriistrinya yang berbeda.

Penampilan fisik (busana) yang dilakukan oleh para suami yang melakukan poligami berkaitan erat dengan berbagai faktor, yaitu:

(a) Apakah istri pertama mengetahui suami poligami atau tidak 
(b) Jadwal 'gilir' yang menjadi keharusan yang dilakukan oleh para suami yang berpoligami.

Konsep impression management yang digagas dalam dramaturgi, khususnya melalui penampilan busana, sangat menunjang pengelolaan citra yang diharapkan oleh para suami yang melakukan poligami untuk memupuk kesan tetap setia terhadap istri pertamanya. Hal ini khususnya dilakukan oleh mereka yang poligaminya tidak diketahui istri pertama, seperti pakaian yang ada di rumah istri kedua tidak boleh dibawa ke istri pertama, karena itu akan menjadi pertanyaan, bahkan pertengkaran dengan istri pertama. Hal ini berbeda dengan mereka yang poligaminya sudah diketahui oleh istri pertama, sehingga ketika jadwal pertemuan dengan istri kedua yang sepengetahuan istri pertama, maka pakaian yang dikenakan pada saat pergi dari rumah istri pertama kemudian pulang kembali ke istri pertama bisa berubah. Demikian sebaliknya.

Artefak (pemilihan barang), selain busana, tentunya juga berkaitan dengan poligami yang dilakukan para suami. Sama halnya dengan busana bagi suami yang melakukan poligami, maka artefak yang dipunyai (apakah itu sepatu, tas, ataupun lainnya) menjadi tersedia di dua tempat, yaitu istri kesatu dan istri kedua. Yang menarik, hasil penelitian ini menunjukkan bahwa ketersedian artefak atau busana dari para suami yang dibelikan oleh istri kesatu atau istri kedua seringkali penempatannya menjadi kacau. Tidak demikian dengan suami yang melakukan poligami dan tidak diketahui oleh istri pertama. Sekalipun ketersediaan barang ada pada kedua istrinya, namun pemakaian harus sesuai dengan tempatnya. Barang yang ada di istri kedua hanya bisa dipakai pada saat dengan istri kedua.

\section{(5) Konsep waktu}

Waktu menentukan hubungan antarmanusia. Pola hidup manusia dalam waktu dipengaruhi oleh budayanya. T. Hall dalam Mulyana ( 2001: 366 ) membedakan dua macam konsep waktu, yaitu monokronik ( M ) dan polikronik ( P ). Penganut waktu $\mathrm{M}$ cenderung lebih menghargai waktu, tepat waktu dan membagi-bagi serta menepati jadwal waktu secara ketat, mereka menekankan penjadwalan dan kesegeraan waktu. Penganut waktu P, cenderung lebih santai, berjalan lebih lambat, suka menunda-nunda pekerjaan. Waktu berhubungan erat dengan perasaan hati dan perasaan-perasaan manusia. Kronemika adalah studi dan interpretasi atas waktu sebagai pesan. Bagaimana orang mempersepsi waktu dan memperlakukan waktu secara simbolik menunjukkan jati diri seseorang.

Konsep waktu menjadi begitu penting dalam kehidupan para bapak yang melakukan poligami. Mereka perlu membagi waktu, khususnya dalam pertemuan dengan istri pertama maupun dengan istri kedua.

"Saya punya jadwal di istri kedua setiap hari Rabu dan Kamis, sehingga setiap jadwal tersebut saya harus mematuhinya untuk berkunjung ke istri kedua. Sementara istri pertama-pun harus rela untuk berbagi waktu dari setiap minggunya" (wawancara dengan Bapak H).

"Saya memang tidak ada jadwal yang pasti hari ini dan itu, tapi dalam setiap minggu saya berkunjung ke istri kedua selama 3 hari" (wawancara dengan Bapak U).

Konsep waktu monokronik yang menghargai waktu, tepat waktu, dan membagi-bagi serta menepati jadwal waktu secara ketat, di mana mereka menekankan penjadwalan dan kesegeraan waktu berdasarkan hasil penelitian dianut oleh para suami yang berpoligami. Pembagian waktu yang sangat ketat perlu ditaati oleh para suami yang berpoligami karena mereka harus adil dalam berbagi diantara kedua istrinya. Bila hal itu tidak dilakukan tentunya para istri akan marah dan dari sisi aturan agama tentunya telah menyalahi "keadilan" yang menjadi hak istri-istrinya. Tidak demikian dengan suami yang poligaminya tidak diketahui oleh istri pertama, maka jadwal pertemuan dengan istri kedua menjadi tidak tetap. Sebagai konsekuensinya istri kedua harus menerima jadwal yang tidak tetap seperti itu.

\subsection{Pembahasan Hasil Penelitian.}

Menurut Goffman, kehidupan sosial itu dapat dibagi menjadi wilayah depan dan wilayah 
belakang. Wilayah depan disebut juga front region atau front stage, merujuk pada peristiwa sosial yang memungkinkan individu bergaya atau menampilkan peran formalnya yang ditonton khalayak penonton. Sementara, wilayah belakang disebut juga back stage, yaitu bagian belakang panggung tempat dimana para aktor mempersiapkan diri, bersantai atau berlatih.

Dari data hasil penelitian yang diperoleh menunjukkan bahwa para suami yang berpoligami melakukan pengelolaan kesan (impression management) di hadapan istri-istri untuk memperoleh kesan yang sesuai (positif), yaitu sebagai suami yang mencintai istri atau keluarga dan setia terhadap istrinya. Yang menarik dari hasil penelitian ini diperoleh gambaran bahwa pada panggung depan tersebut, para suami yang berpoligami melakukan manipulasi diri dengan menampilkan perilaku rasa sayang yang menjadi lebih kepada istri pertama dibanding ketika sebelum poligami. Hal ini termasuk pada excuses (maaf/mengakui kesalahan) atau dapat dikatakan sebagai because motives dalam konsep Account dari Scott dan Lyman, yang menjelaskan bahwa perilaku yang dilakukan oleh seseorang sebagai pernyataan yang dibuat oleh aktor sosial untuk mengurangi kesalahan mereka sendiri pada yang tidak baik atau tindakan-tindakan yang tidak dapat diantisipasi.

Schutz (dalam Littlejohn, 2006:256) mengartikan bahwa accounts sama dengan motive, artinya dorongan untuk melakukan sesuatu, termasuk di dalamnya keinginan untuk berinteraksi dan berkomunikasi, atau suatu tindakan yang dilakukan atas dasar dorongan dalam diri manusia. Sedangkan Scott dan Lyman, memandang bahwa tindakan atau hasrat untuk berinteraksi tersebut didasari atas tanggung jawab. Tidak sertamerta berbuat begitu saja.

Poligami yang dilakukan oleh para suami, ternyata juga membawa hikmah pada kehidupan seksual dengan istri-istrinya, hal ini disampaikan oleh seorang responden yaitu:

"Setelah menikah dengan istri kedua, banyak hal yang bapak rasakan berbeda dan ada hikmahnya. Pertama, rizki bapak menjadi bertambah, buktinya

\section{Gambar 1: Model Dramaturgi Poligami}

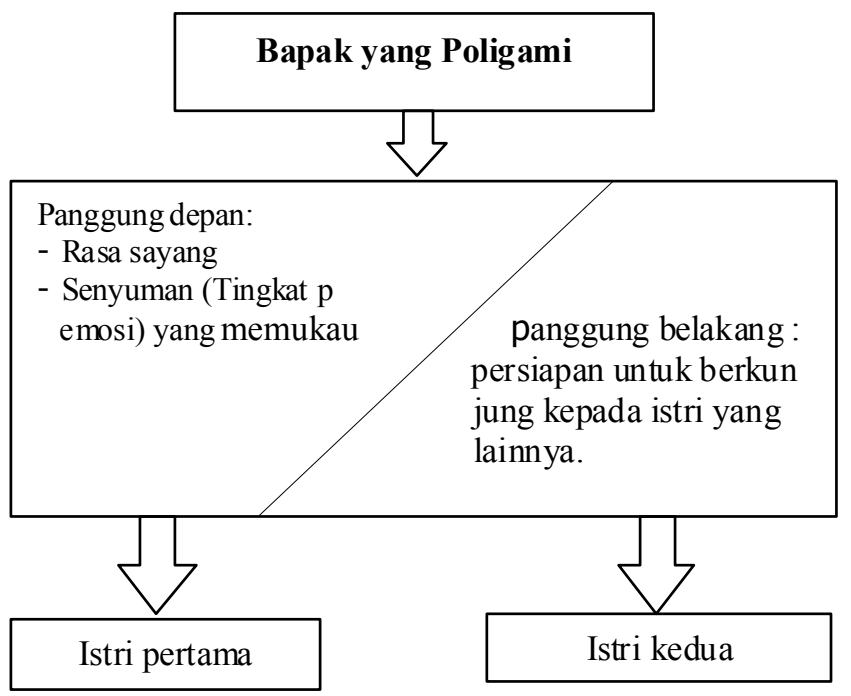

Sumber: Hasil Penelitian Juli 2007 
Gambar 2:

Model Penggunaan Simbol Nonverbal dalam Dramaturgi Poligami.

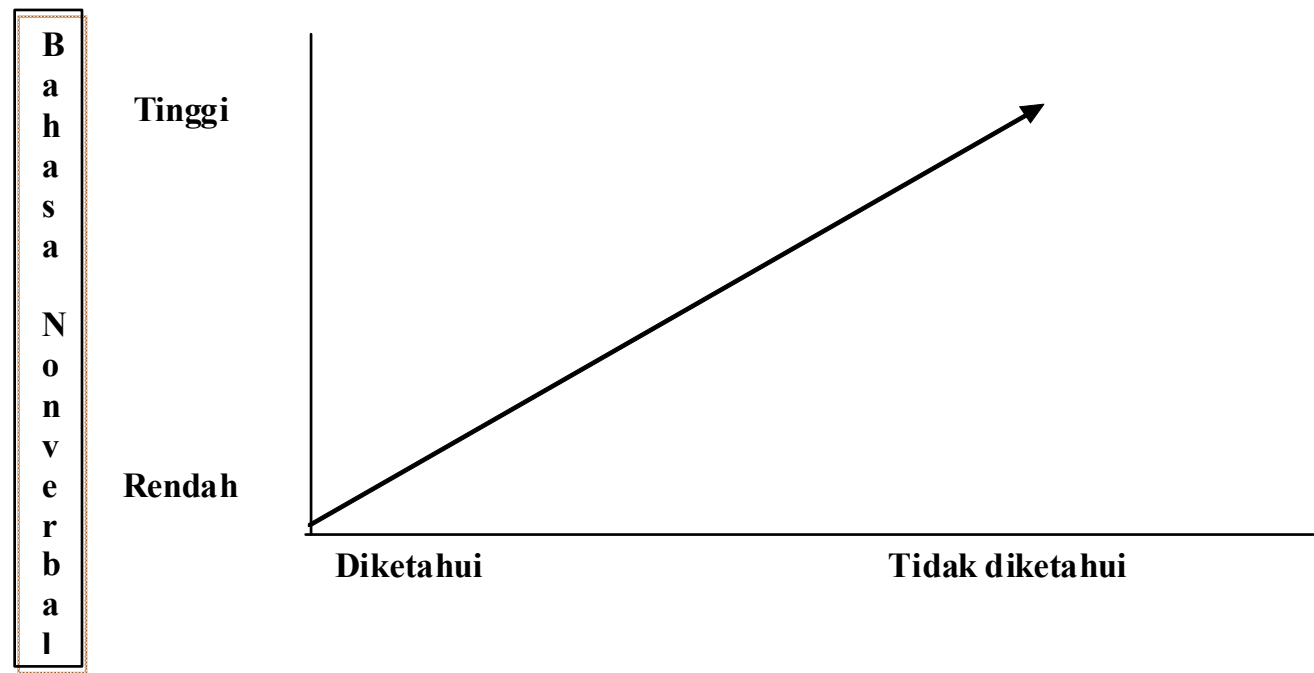

Sumber: Hasil Penelitian Juli 2007

bapak dapat menghidupi kedua istri tanpa harus mengurangi bagian gaji dari istri pertama. Kedua, gairah seksual menjadi terperihara, bahkan meningkat, apalagi istri kedua bapak jauh lebih muda. Ketiga, bapak merasa menjadi lebih muda lagi” (wawancara dengan Bapak U).

Temuan lain yang menarik dari hasil penelitian ini adalah adanya "pencampuradukan" panggung depan sekaligus menjadi panggung belakang, dengan adanya manipulasi diri yang dilakukan oleh suami yang poligami. Panggung depan sekaligus menjadi panggung belakang bagi suami yang melakukan poligami akan dilakukan di hadapan istri pertama. Dengan demikian meminjam istilah Arrianie, telah terjadi "kekacauan panggung" yang digunakan oleh suami yang berpoligami. Suami yang berpoligami akan mengelola kesan yang positif di hadapan istri pertama, namun sekaligus menjadi panggung belakang ketika hal itu akan dilakukan sebagai persiapan untuk berkunjung kepada istri kedua. Demikian sebaliknya. Hal ini akan sangat kuat atau kentara sekali dilakukan oleh suami yang poligaminya tidak diketahui istri pertama. Bila digambarkan, tampak pada gambar 1 .

Konsep pengelolaan kesan yang dilakukan oleh para suami yang berpoligami pada akhirnya tidak terlepas dari penggunaan simbol verbal dan nonverbal dalam berkomunikasi dengan para istrinya. Nonverbal yang ditampilkan akan sangat tergantung pada diketahui tidaknya poligami yang dilakukan oleh istri pertama. Pesan nonverbal yang digunakan dalam pengelolaan kesan di hadapan istri-istrinya, meliputi; penampilan pisik (busana dan artefak), para bahasa, sentuhan, dan konsep waktu. Dari hasil penelitian ini diperoleh temuan bahwa dengan tidak diketahuinya poligami yang dilakukan, maka semakin tinggi penngunaan simbol nonverbal. Bila digambarkan, tampak pada Gambar 2 . 


\section{Kesimpulan}

Berdasarkan hasil penelitian yang dilakukan mengenai poligami yang dilakukan oleh para suami diperoleh kesimpulan sebagai berikut:

(1) Pengelolaan kesan di panggung depan atau front stage dan juga panggung belakang atau back stage dilakukan oleh suami yang berpoligami untuk memperoleh kesan setia, sayang istri, atau kesan positif lainnya di hadapan istri-istrinya melalui bahasa verbal maupun nonverbal.

(2) Telah terjadi pencampuradukan panggung depan dan belakang pada pengelolaan kesan yang dilakukan oleh suami pelaku poligami, yang dipengaruhi keterbukaan poligami di hadapan istri pertama.

(3) Pesan nonverbal akan sangat memengaruhi proses komunikasi dari pasangan poligami, khususnya yang masih tersembunyi.

\section{Daftar Pustaka}

Bungin, Burhan. 2003. Analisis Data Penelitian Kualitatif, Jakarta Raja Grafindo Persada.

Clayton, Peter. 2005. Bahasa Tubuh dalam Pergaulan Sehari-hari, terjemahan Aleksander Sindoro, Batam, Karisma Publishing Group.

Effendy, Onong Uchyana. 2000. Ilmu, Teori dan Filsafat Komunikasi, Bandung. Citra Adhitya Bhakti.

Garna, K Judistira. 1999. Metoda Penelitian: Pendekatan Kualitatif, Bandung, Primaco Akademika.
Istibsyaroh. 2004. Poligami dalam Cita dan Fakta, Bandung, Mizan Media Utama

Knapp, Mark Land Judith, A.Hall. 1992. Nonverbal communication In Human Interaction, New York, Horcout Brace Javanovich College Publishers.

Littlejohn, Stephen W. 2006. Theories of Human Communication, Fifth edition, California, Belmonth: Wadsworth.

Matthew, Miles B. dan Michael Humberman. 1992. Analisis Data Kualitatif, Jakarta, UI Press.

Moleong, J. Lexi. 2004. Metodologi Penelitian Kualitatif, Bandung, Rosdakarya.

Mubarak, Saiful Islam. 2007. Poligami antara Pro dan Kontra, Bandung, Penerbit Syaamil.

Mulia, Siti Musdah. 2007. Islam Menggugat Poligami, Jakarta, Kerjasama LKAJ, Gramedia Pustaka Utama, dan The Asia Foundation.

Mulyana, Deddy. 2001a. Ilmu Komunikasi Suatu pengantar, Bandung, Rosda Karya. . 2001b. Metodologi Penelitian Kualitatif, Paradigma Baru Ilmu Komunikasi dan Ilmu sosial Lainnya, Bandung, Rosda Karya.

,2004. Komunikasi Efektif, Suatu Pendekatan Lintasbudaya, Bandung, Rosdakarya.

Rakhmat, Jalaluddin.1995. Metode Penelitian Komunikasi, Bandung, Rosda Karya. Bandung, Rosda Karya.

Tubbs.L Stewart - Sylvia Moss. 2001. Human Communicaation, Prinsip-Prinsip Dasar, Bandung, Rosdakarya. 
